\title{
IAMJ
}

INTERNATIONAL

AYURVEDIC

MEDICAL JOURNAL

\section{PHARMACOGNOSTICAL, PHYSICOCHEMICAL AND PHYTOCEMICAL STUDY OF Glycyrrhiza Glabra Linn.}

\author{
Richa Khandelwal ${ }^{1}$, Sumit Nathani ${ }^{2}$, Gaurav Sharma ${ }^{3}$ \\ ${ }^{1} \mathrm{Ph} . \mathrm{D}$. Scholar, ${ }^{2}$ Assistant Professor, ${ }^{3}$ Pharmacologist, \\ P.G. Department of Dravyaguna Vigyan, National Institute of Ayurveda, Jaipur, Rajasthan, India
}

Corresponding Author: khandelwalricha98@gmail.com

https://doi.org/10.46607/iamj0308112020

(Published online: November 2020)

Open Access

(C) International Ayurvedic Medical Journal, India 2020

Article Received: 06/10/2020 - Peer Reviewed: 08/11/2020 - Accepted for Publication: 12/11/2020

\section{Check for updates}

\section{ABSTRACT}

Introduction - Glycyrrhiza glabra Linn. is a perennial herb of family Leguminoseae, used very extensively in Ayurveda classics. It is having property of aphrodisiac, trichogenous, expectorant, haemostatic, intellect promoting etc. Objective - Objective of this study to examine the Pharmacognastical and Phytochemical properties of Glycyrrhiza glabra Linn. Material and Method - Dry sample of Glycyrrhiza was collected from Market. The qualitative microscopy, phytochemical screening, physicochemical evolution and TLC studies were carried out according to the standard procedure recommended by API and other standards. Result -The sample is having sweetish taste, faint and characteristic odour, externally dark brown in colour and internally golden yellow. Cork, Phellogen and Phelloderm, Secondary phloem, Cambium, Secondary xylem, Medullary rays and Pith are present in microscopic examinations, from outer to inner side. Cork (in surface view), Tangentially cut medullary ray cells, Fragment of vessel, Calcium Oxalate Crystals, Starch, Mucilage were seen in powder microscopy. $\mathrm{pH}$ value of test sample was 5.73. Water Soluble Extractive value (25.0064\%) was more than Alcohol Soluble Extractive value (12.7398 \%). Total ash value of test sample was $6.131 \%$. Acid insoluble ash value was $0.79 \%$, Water soluble ash value was $\mathbf{1 . 8 1 9} \%$. In TLC, $R_{\mathrm{f}}$ values were found $0.23,0.58,0.71$ after derivatization with vanillin Sulphuric acid reagent. Carbohydrate, alkaloid, amino acid, tannin, protein, saponin, glycosides, flavonoids and tannin were present in the sample. Conclusion - test sample of Glycyrhiza complies all standard when matches 
with the reference standard book. It suggests that test sample is authentic and without any impurities and adulteration.

Keywords - Glycyrrhiza glabra Linn., Pharmacognostical study, Microscopy, Macroscopy, Physico-chemical analysis, Phytochemical analysis, Thin Layer Chromatography.

\section{INTRODUCTION}

Medicinal plants are being used for centuries for treating a variety of ailments in different traditional systems of medicine. Now a day, global interest has been developed in different traditional health care system as a safer option. Herbal industry is the growing industry as a billion-dollar industry these days due to increasing demand of medicinal plants. As demand is increasing, quality, safety and efficacy are major concerns which come into account. There is a lot of variation in raw plant material due to various reasons, like closely related species, climate variation, seasonal variations, different drying procedures and storage practices. That's why standardization is considered necessary.

Standardization is the process of evaluation of the quality and purity of crude drugs by means of various parameters like morphological, microscopical, physical, chemical and biological observations ${ }^{1}$.Standardization starts right from the collection of raw materials upto their clinical application. In case of Ayurveda medicines, the therapeutic efficacy is also related to its chemical constituents. The quality and purity refer to the total profile of the drug rather than any of its character. Therefore, a multidimensional approach is essential for standardizing a Ayurveda drug.

Glycyrrhiza glabra is well known plant of Ayurveda classics and well described as name of Madhuka, Yashtimadhu, Madhuyashti etc. in different Ayurveda text. It belongs to the Leguminosae family. G. glabra is a typical herbaceous perennial, growing to $1 \mathrm{~m}$ in height, presenting pinnate leaves with a length of 7 to $15 \mathrm{~cm}$. The flowers are purple to pale whitish blue, being arranged in a hermaphrodite inflorescence, whereas the fruit is an oblong legume with 2 to $3 \mathrm{~cm}$ of length and containing several seeds ${ }^{2}$
It is distributed in the Sub-tropical and warm temperature regions of the world chiefly in the Mediterranean countries, south Europe, Asia Minor, Egypt, Turkistan, Iran, Siberia, Persia, Arab countries and Afghanistan. In India, it is reported to be cultivated in Baramulla, Srinagar, Jammu, Dehradun and Delhi ${ }^{3}$.

It is very extensively used in Ayurveda for different ailments. Acharya Charak added Yashtimadhu in 11 Mahakashayas among 50 mahakashayas ${ }^{4}$. It is the drug, which has been used most frequently in Mahakashaya than any other drug. Among 36 groups of drugs (gana) of Sushrut Samhita, Madhuka is included in 8 groups (Gana) ${ }^{5}$. In Ashtanga Hridaya, Madhuka has been included in ten out of thirty-three Gana $^{6}$. It expresses that it is a broad-spectrum drug which is used very extensively in Ayurveda pharmacology.

The roots are sweet, cold in potency, emetic in large doses, tonic, diuretic, demulcent, mild laxative, aphrodisiac, trichogenous, expectorant, emmenagogue, alexipharmic, haemostatic, alterant and intellect promoting ${ }^{7}$. Other pharmacological actions are Smooth muscle depressant, anti-microbial, hypolipidaemic, antiantherosclerotic, antiviral, hypotensive, hepatoprotective, anti-exudative, spasmolytic, antidiuretic, antiulcer, antimutagenic, antipyretic, antioxidant, antiinflammatory, anti-nociceptive, expectorant ${ }^{8}$.

The aim of this paper is to present an overview of pharmacognostical, physic-chemical and phytochemical investigations carried out on the market sample of plant Glycyrrhiza glabra Linn. for proper authentication \& identification of the drug and for analyze quality and safety of the drug.

\section{Material and Methods}

\section{Collection of Sample}

Dry sample of Madhuka was purchased from Jaipur crude drug market after proper identification. The 
plant material was authenticated from Raw Material Herbarium and Museum, Delhi (RHMD) of National Institute of Science Communication and Information Resources (NISCAIR) with Ref. no. NISCAIR/RHMD/Consult/2016/2977-04.

Macroscopic Study: The collected sample of Madhuka studied organoleptically, with naked eye \& magnifying lens, with the help of pharmacognostical procedure i.e. appearance, size, shape, colour, and odour and findings were recorded.

\section{Microscopic Study:}

Collected Sample of Glycyrrhiza glabra Linn was dried that's why it was be soaked in water for overnight, still it was hard, so it was boiled in water for 15-20 minutes for softening. After softening sample was cut into thin sections with the help of blade and were put in water for some time. Then the sections were soaked in safranin stain for $5 \mathrm{~min}$. \& then transferred to a watch glass with plain water, so that excess stain gets washed away. The sections were transferred on a glass slide $\&$ few drops of glycerin water added on it. With the help of a needle, a cover slip was placed on the section gently and then the slides were observed in microscope \& photos were taken.

\section{Powder Microscopy}

For examining the characters of the powder, sufficient amount of powder was taken in different chemical reagents then after place on different slide and warmed over a low flame for a short time. A Drop of glycerin was put on the powder on the slide, covered it with the cover slip and observed under the microscope. Chemical reagents used for staining are Safranin, Dilute Ferric chloride, Methylene blue, Eosin aqueous solution and Iodine solution.

\section{Physicochemical Analysis}

Assessment of the parameters such as moisture content, foreign matter, ash value, acid insoluble ash, water-soluble extractive, alcohol soluble extractive, and $\mathrm{pH}$ was carried out by following standard procedures recommended by Ayurvedic Pharmacopoeia of India and other standard texts ${ }^{9,10,11,12}$

Phytochemical Analysis

Freshly prepared extracts were tested for the presence of various active phyto compounds. Presence of car- bohydrates (Molisch's Test, Benedict's test, Barfoed's test, Fehling solution test), alkaloids (Mayer's test, Dragondroff's test, Wagner's Test, Hager's Test), amino acids (Ninhydrin test), proteins (Biuret test, Xanthoprotic test, Millons test), saponins (Foam test), glycosides (Keller - Killiani Test, Borntragor's test), Phenolic Compound, flavonoids (Shinoda test), steroids (Salkowski test) and tannins (Ferric chloride solution, Lead acetate test, Pot. Dichromate test) were tested ${ }^{13}$

\section{Chromatography}

Procedure was done as mentioned in the Quality Standards of Indian Medicinal Plants, Vol. $9^{14}$. which is as follows -

TLC plate and Activation of Plate - T.L.C. plate coated with $0.25 \mathrm{~mm}$ layer of silica gel $60 \mathrm{~F}_{254}$ with fluorescent indicator was used. (Each plate dimension is $10 \mathrm{~cm}$ long and $2 \mathrm{~cm}$ width). Then, Activation of pre-coated Silica gel $60 \mathbf{F}_{\mathbf{2 5 4}}$ was done. Plates were dried in hot oven at $105^{\circ} \mathrm{C}$ for one and half hour for activation.

Preparation of mobile solution - Mobile solution was prepared with n-Butanol: Water: Glacial acetic acid in the ratio $7: 2: 1$

Preparation of test solution -4 gm powdered drug was extracted with $100 \mathrm{ml}$ of ethanol (90 percent) in a Soxhlet apparatus consecutively three times. Extract was filtered and concentrated to $10 \mathrm{ml}$.

Sample application - Sample was applied with the help of capillary 1(one) $\mathrm{cm}$ above the base of T.L.C. plate. Then it was dipped in mobile solution. T.L.C. plate was removed from the mobile solution immediately after the spot reached the 1 (one) $\mathrm{cm}$ below the top of the T.L.C. plate.

Visualization - The plate was sprayed with vanillinSulphuric acid reagent and heated at $105^{\circ}$ for 5 to 10 min. $\mathrm{R}_{\mathrm{f}}$ value and colour of the resolved bands are recorded.

Rf Value- Measured and recorded the distance of each spot from the point of its application and calculated $\mathrm{R}_{\mathrm{f}}$ value by dividing the distance travelled by the spots by the distance travelled by the front of the mobile phase. 


\section{Results}

\section{Macroscopic evaluation}

In macroscopic examination it is observed that pieces of stolon were cylindrical, straight, variable in length, $1-2 \mathrm{~cm}$ in diameter, externally dark brown in colour and internally golden yellow, externally longitudinally wrinkled, with occasional small buds, encircling scale leaves, transversely smooth, cut surface shows a cambium ring about one-third of radius from outer surface and a small central pith. Odour is faint and characteristic, taste is sweetish.
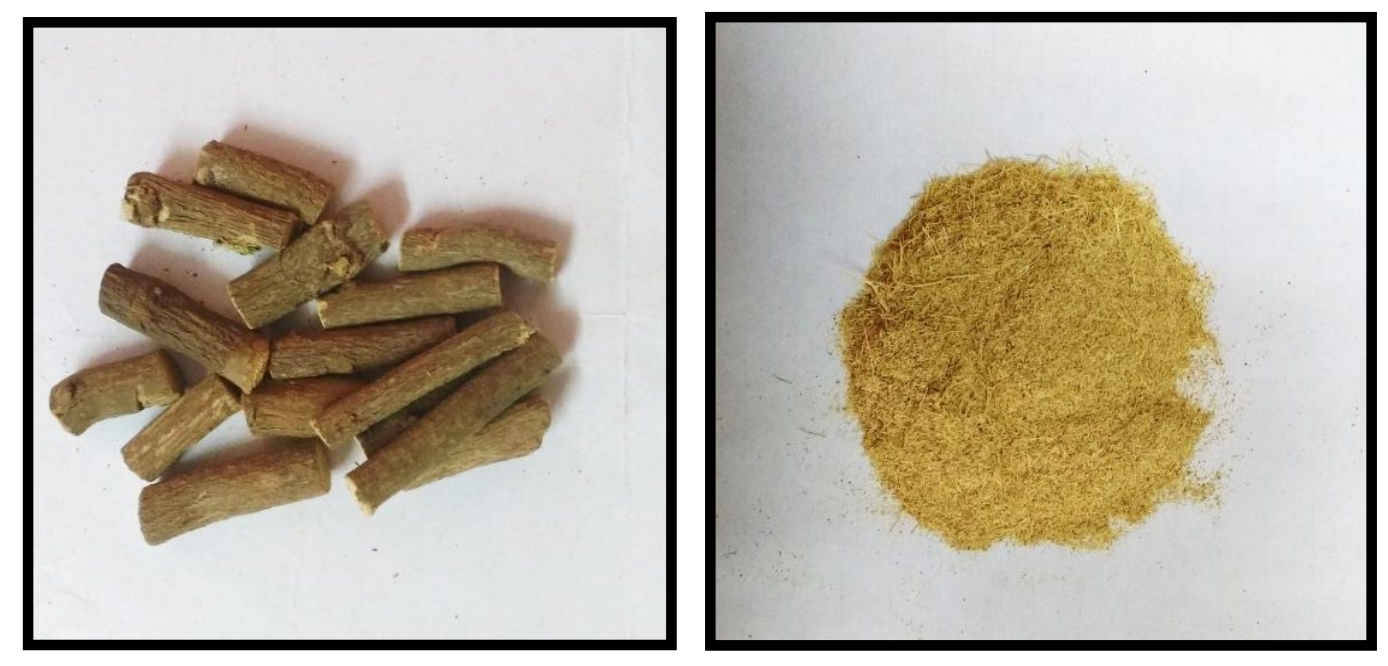

Figure 1: Crude and Powdered drug used for the study

Microscopic evaluation: T.S. of stolon was circular in outline, showing the following structures -

(As shown in figure no. 1)

Cork - Numerous layers (around 10-20) of tubular cells, outer layers with reddish-brown amorphous contents, inner 3 or 4 rows having thicker, colourless walls.

Phellogen and Pheloderm - Not separately distinguish, 3-5 rows of cells having thicker wall. It may a part of secondary cortex.

Secondary phloem- It is part of secondary cortex, it is abroad band which contains -

- Phloem Fibers - About 10-20 fibers are radially arranged, inner cells are cellulosic and outer part of phloem fibers is lignified. Intercellular spaces present.

- Phloem parenchyma - Phloem fibers are surrounded by a sheath of parenchyma cells. It may contain calcium oxalate crystals.
- Medullary rays

Cambium - Cambium is distinct, form of 3 to 5 layers of cells.

Secondary xylem - It contain -

- Xylem vessels - Vessels are round with thick, yellow, pitted, reticulately thickened walls.

- Xylem fibers - Lignified with crystal sheaths similar to those of phloem.

- Xylem parenchyma - Parenchyma of two kinds, those between the vessels having thick pitted walls without inter-cellular spaces, the remaining with thin walls

\section{- Medullary rays}

Medullary rays - Distinct, radially arranged 3-5 rows of parenchymatous cells from xylem to phloem, narrow in the xylem region and wider in the phloem region.

Pith - form of thin walled parenchymatous cells with intercellular spaces. 
Figure 1a: (A, B, C, D) Microscopy of Stolon of Glycyrrhiza glabra Linn.
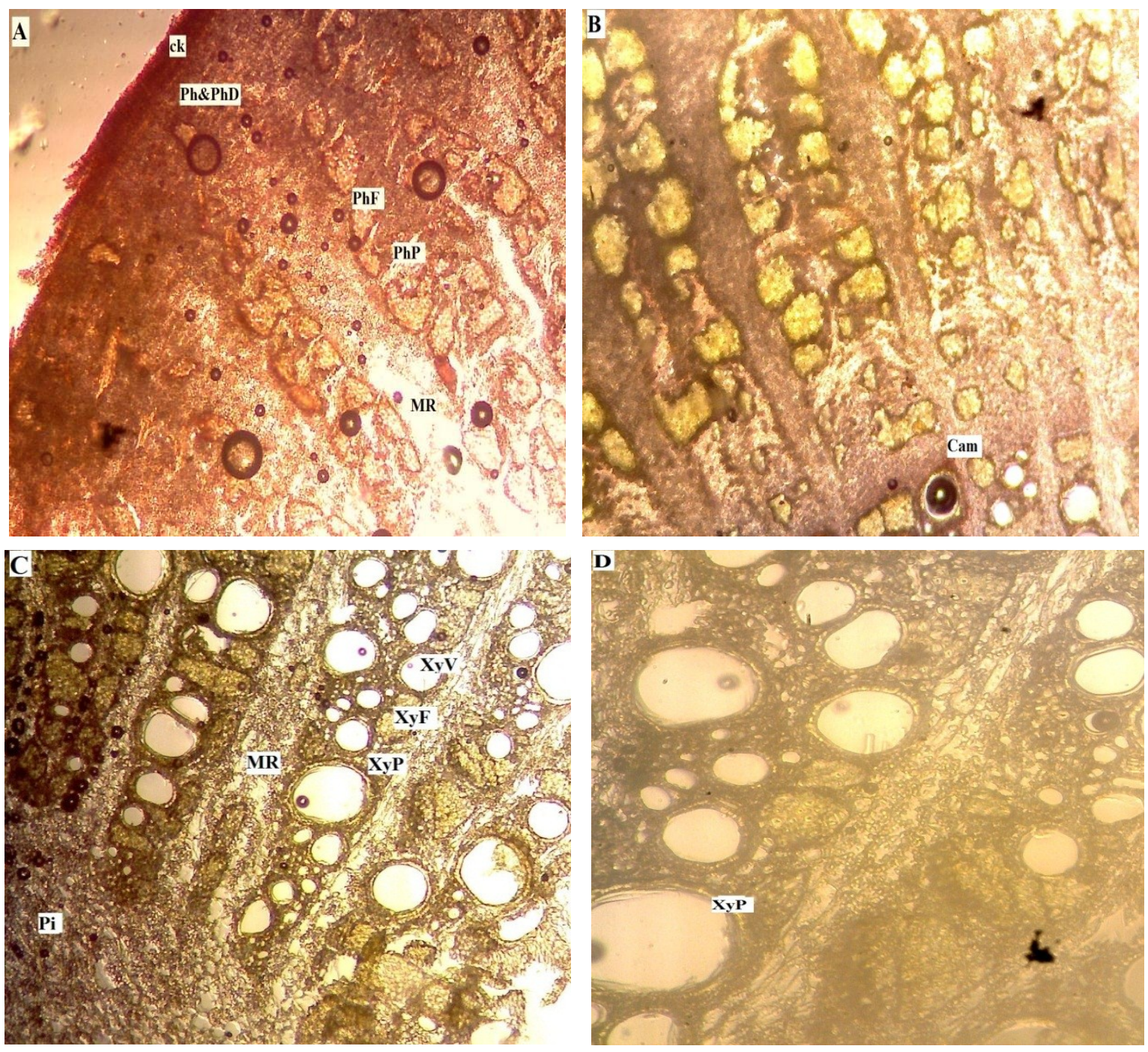

ck - cork, Ph \& PhD - Phellogen \& Phelloderm, PhF - Phloem Fibers, PhP - Phloem Parenchyma, MR Medullary Rays, Cam- Cambium, XyV - Xylem Vessels, XyF - Xylem Fibers, XyP - Xylem Parenchyma, Pi - Pith,

Powder microscopy - Powder microscopy of Glycyrrhiza shows presence of Calcium Oxalate
Crystals, starch grains, surface view of cork, tangentially cut medullary ray cells with associated parenchyma, Fragment of vessel with elongated bordered pits, deep blue colour of mucilage. (As shown in figure no. 2) 
Figure 2: Powder Microscopy of Glycyrrhiza glabra Linn. Powder

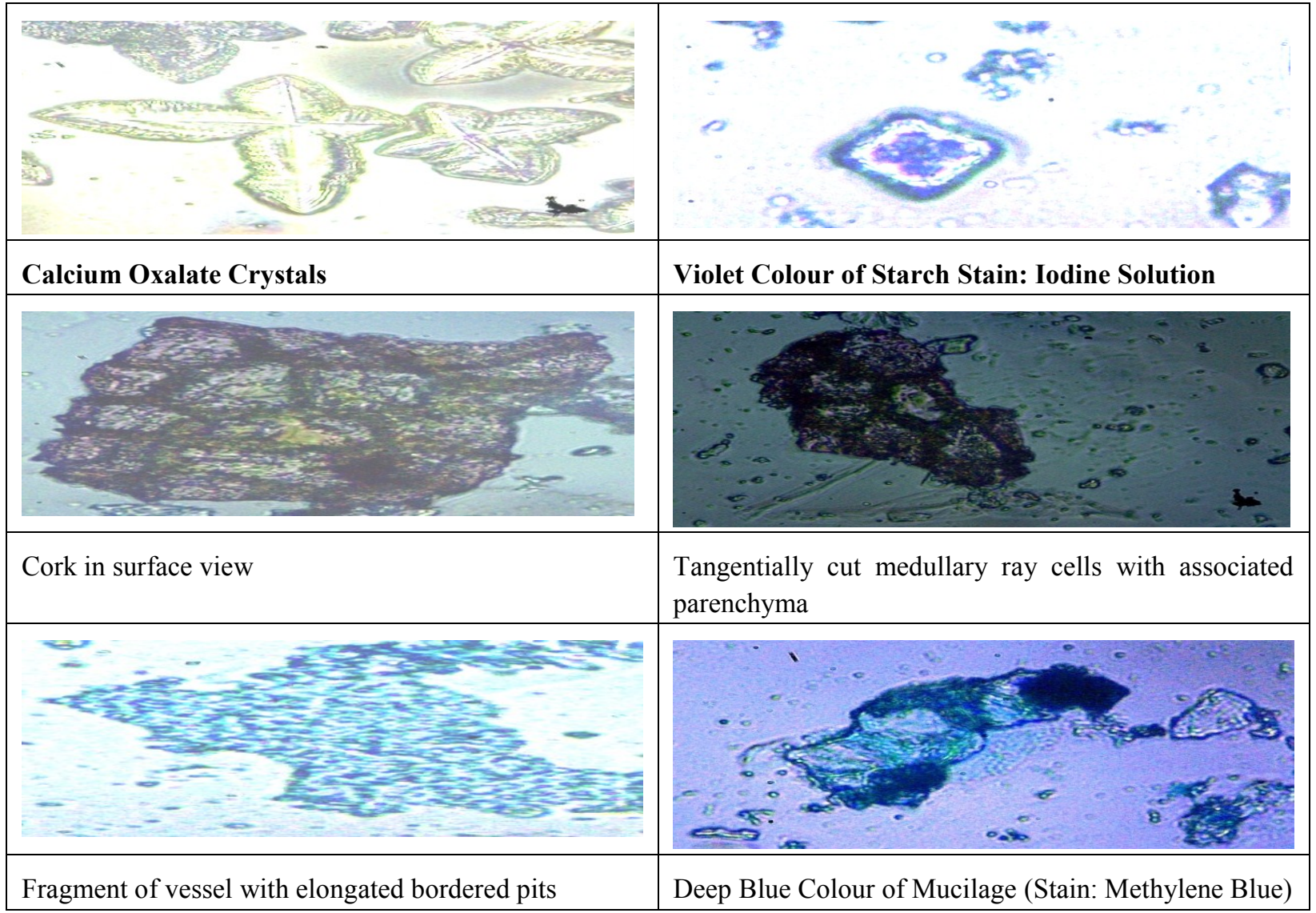

Physicochemical analysis: Detailed results of physicochemical analysis are given in Table 1.

Table 1: Physicochemical analysis of Glycyrrhiza glabra (stolon) powder

Physicochemical parameter

Moisture content

pH

Ash Value

Acid Insoluble Ash

Water Soluble Ash

Water soluble Extractive value

Alcohol Soluble Extractive value

Phytochemical analysis: The qualitative phytochemical test revealed presence of carbohydrate, alkaloids, amino acids, proteins, saponins and tannins in aqueous

\section{Result (w/w)}

$5.525 \%$

5.73

$6.131 \%$

$0.79 \%$

$1.819 \%$

$25.0064 \%$

$12.7398 \%$

Table 2 Qualitative analysis of Glycyrrhiza glabra (stolon) in aqueous and alcoholic extract

\begin{tabular}{|l|l|l|}
\hline Name of Test & Aq. Ext. & Alco. Ext. \\
\hline Carbohydrate & \multicolumn{2}{|l}{} \\
\hline Molish's test & -ve & -ve \\
\hline Benedict test & + +ve & + +ve \\
\hline
\end{tabular}




\begin{tabular}{|c|c|c|}
\hline Fehling test & $+v e$ & -ve \\
\hline Barfoed's test & -ve & -ve \\
\hline \multicolumn{3}{|l|}{ Alkaloids } \\
\hline Dragendorff test & $+v e$ & -ve \\
\hline Wagner's test & -ve & +ve \\
\hline Mayer's test & -ve & +ve \\
\hline Hager's test & $+v e$ & $+v e$ \\
\hline \multicolumn{3}{|l|}{ Amino acids } \\
\hline Ninhydrine test & $+v e$ & -ve \\
\hline \multicolumn{3}{|l|}{ Protein } \\
\hline Biuret test & -ve & -ve \\
\hline Xanthoproteic test & -ve & -ve \\
\hline Millon's test & $+v e$ & -ve \\
\hline \multicolumn{3}{|l|}{ Saponin } \\
\hline Foam test & $+\mathbf{v e}$ & -ve \\
\hline \multicolumn{3}{|l|}{ Glycosides } \\
\hline Keller kiliani test & -ve & + ve \\
\hline Borntrager's test & -ve & +ve \\
\hline \multicolumn{3}{|l|}{ Phenolic compound } \\
\hline Phenolic compound & -ve & -ve \\
\hline \multicolumn{3}{|l|}{ Flavonoids } \\
\hline Shinoda test & -ve & $+v e$ \\
\hline \multicolumn{3}{|l|}{ Steroids } \\
\hline Salkowski tests & -ve & -ve \\
\hline \multicolumn{3}{|l|}{ Tannins } \\
\hline $\mathrm{Fecl}_{3}$ & -ve & -ve \\
\hline Lead acetate & $+v e$ & $+v e$ \\
\hline Pot. Dichromate & -ve & -ve \\
\hline
\end{tabular}

Chromatography: Result of TLC Screening Ethanolic Extract of Glycyrrhiza glabra Linn was shown in Table 3.

Table 3: TLC Screening of Ethanolic Extract of Glycyrrhiza glabra Linn.

After derivatization by vanillin-sulphuric acid in UV spectrophotometer (long reagent

$\mathrm{R}_{\mathrm{f}}$ Value $-0.23,0.58,0.71$

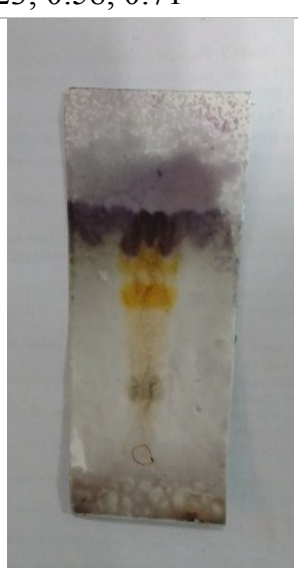
waves)

$\mathrm{R}_{\mathrm{f}}$ Value- $0.69,0.80$

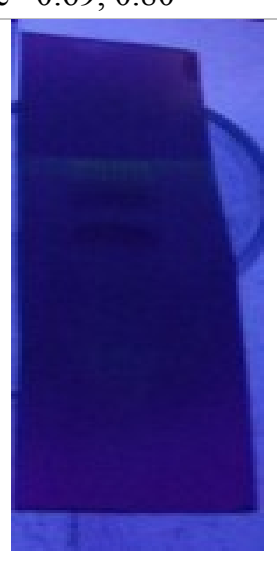

in UV spectrophotometer (short waves)

$0.29,0.64,0.70,0.80$ 


\section{DISCUSSION}

In Macroscopic study, test sample of madhuka that is Glycyrrhiza glabra Linn. has its peculiar characteristics like sweetish taste, faint and characteristic odour, externally dark brown in colour and internally golden yellow, externally longitudinally wrinkled, with occasional small buds etc. Glycyrrhiza glabra Linn. Root was similar, without a pith, fracture, coarsely fibrous in bark and splintery in wood. On the basis of macroscopic characters stolon part is differentiated with root of Glycyrrhiza glabra or any other adulterations.

In microscopic study, structures which were found from outer to inner were Cork, Phellogen and Phelloderm, Secondary phloem, Cambium, Secondary xylem, Medullary rays, Pith. These findings match with the standards that are given in Quality Standards of Indian medicinal plants, ICMR, vol. 9.and API, vol. 1. In Powder microscopy structures like cork (in surface view), Tangentially cut medullary ray cells with associated parenchyma, Fragment of vessel with elongated bordered pits were seen. Other than these structures Calcium Oxalate Crystals, Starch, Mucilage were also seen in powder microscopy. These findings match with the standards that are given in Quality Standards of Indian medicinal plants, ICMR, vol. 9. and API vol. 1 .

$\mathrm{pH}$ value of test sample was 5.73 that shows its acidic nature.

Alcohol Soluble Extractive value of tests ample has been found $12.7398 \%$ and Water-Soluble Extractive value has been found $25.0064 \%$, which matches with the standards mentioned in the API indicates the probability of the presence of high water-soluble constituents than the alcohol-soluble constituents.

Ash values are used to determine quality and purity of crude drug. It indicates presence of various impurities like carbonate, oxalate and silicate. The water-soluble ash is used to estimate the amount of inorganic compound present in drugs. The acid insoluble ash consist mainly silica and indicate contamination with earthy material ${ }^{15}$.

Total ash value of test sample is $\mathbf{6 . 1 3 1} \%$. Acid insoluble ash value is $\mathbf{0 . 7 9} \%$, Water soluble ash value is $\mathbf{1 . 8 1 9} \%$. These values match with the standards men- tioned in the API. It is suggested that no impurities in our sample.

Thin layer chromatography is a technique for separation and identification of chemical constituent present in the herbs or chemical mixtures. With mobile solution of n-Butanol: Water: Glacial acetic acid with 7: 2:1 ratio, Ethanolic extract of root of Glycyrrhizaglabra Linn. shows $\mathrm{R}_{\mathrm{f}}$ values $0.23,0.58,0.71$ after derivatization with vanillin - Sulphuric acid reagent which are matches with the standard given in Quality Standards of Indian medicinal plants, ICMR, vol. 9.In UV spectrophotometer (long waves) $\mathrm{R}_{\mathrm{f}} \mathrm{Val}$ ues $-0.69,0.80$ and in UV spectrophotometer (short waves) $\mathrm{R}_{\mathrm{f}}$ Values $0.29,0.64,0.70,0.80$

In phyto-chemical analysis of test sample, it was reported that carbohydrate, alkaloid, amino acid, tannin, protein, saponin, glycosides, flavonoids and tannin were present in the sample. This means test sample contains both primary \& secondary metabolites which are required for plant's growth $\&$ are present in a plant when plant is fully grown. It means sample was authentic one.

\section{CONCLUSION}

On the basis of these pharmacognostical and phytochemical findings it was observed that the test sample madhuka which is used for the study complies all standard when matches with the reference standard book. It suggests that test sample is authentic and without any impurities and adulteration. The result of the present study can be considered as the reference values for similar research works in future.

\section{REFERENCES}

1. Khandelwal K. R. 2013, Practical Pharmacognosy, $2^{\text {nd }}$ Ed, Nirali Prakashan, Pune, 23.1-23.4.

2. Pastorino G, Cornara L, Soares S, Rodrigues F, Oliveira MBPP. Liquorice (Glycyrrhizaglabra): A Phytochemical and Pharmacological Review. Phytotherapy Research. 2018; 32:2323-2339. https://doi.org/10.1002/ptr.6178

3. Sharma P. C. Yelne M.B. Dennis T.J. Database on Medicinal Plants Used in Ayurveda, Vol. 3, Central Council for Research in Ayurveda and Siddha, Deptt. of ISM \& H, Min. of Health \& Family Welfare, Govern- 
ment of India, 2001, Page no. 561

4. Trikamji Y. (Ed.), Caraka-Samhita of Agnivesha elaborated by Charaka and Dridhbala with the Ayurveda dipika commentary by Chakrapanidatt, Chaukhambha Surbharati Prakashana, Varanasi, 2014 Edition, Sutra Sthan $4^{\text {th }}$ Chapter, verse no. 9-18, pg. no. 32-34.

5. Trikamji J. (Ed.), Acharya N. R. (Ed.), Sushrut Samhita of Sushrut with the Nibandhsangrha commentary of Dalhan Acharya and the Nyayachandrika Panjika of Gayadas Acharya on NidanaSthana, Chaukhambha Surbharti Prakashan, Varanasi, 2017 Edition, Sutra Sthana, Chapter $38^{\text {th }}$, pg. no. 164-170.

6. Shastri H. S. (Ed.), Astanghridaya of Vagbhatta with the commentries - Sarvangsundara of Arundatta and Ayurveda Rasayan of Hemadri, Chaukhambha Surbharti Prakashan, Varanasi, 2016 Edition, Sutra Sthana, Chapter $15^{\text {th }}$, pg. no. 230-240.

7. Sharma P. C. Yelne M.B. Dennis T.J. Database on Medicinal Plants Used in Ayurveda, Vol 3, Central Council for Research in Ayurveda and Siddha, Dept. of ISM \& H, Min. of Health \& Family Welfare, Government of India, 2001, Page no. 562

8. Sharma P. C. Yelne M.B. Dennis T.J. Database on Medicinal Plants Used In Ayurveda, Vol 3, Central Council for Research in Ayurveda and Siddha, Deptt. of ISM \& H, Min. of Health \& Family Welfare, Government of India, 2001, Page no. 563

9. Anonymous. The Ayurvedic Pharmacopoeia of India, Part-I, Volume - I, Appendix -2, Government of India, Ministry of Health and Family Welfare, Department of AYUSH, 2001, page. no. 213-214

10. World Health Organization. Quality Control Methods for Medicinal Plant Materials. Geneva: World Health Organization; 1998. p. 15, 35, 40.

11. Tondon N. (Ed.), Quality Standards of Indian Medicinal Plants, Vol. 9, Indian Council of Medical Research, 2011, page no. 175- 186

12. Lavekar G.S. Pradhi E.E. Pant P., Laboratory guide for the analysis of Ayurveda and siddha formulations, CCRAS, Dept. Of Ayush, ministry of health and family welfare, Govt. of India, New Delhi, 2010, P. 83-87.

13. Lavekar G.S. Pradhi E.E. Pant P., Laboratory guide for the analysis of Ayurveda and siddha formulations, CCRAS, Dept. Of Ayush, ministry of health and family welfare, Govt. of India, New Delhi, 2010, P. 83-87.

14. Tondon N. (Ed.), Quality Standards of Indian Medicinal Plants, Vol. 9, Indian Council of Medical Research, 2011, page no. 175- 186
15. Chanda S. Importance of Pharmacognostic study of medicinal plants: An overview, Journal of Pharmacognosy and Phytochemistry 2014; 2 (5): 69-73

\section{Source of Support: Nil \\ Conflict of Interest: None Declared}

How to cite this URL: Richa Khandelwal et al: Pharmacognostical, Physicochemical and Phytocemical Study of Glycyrrhiza Glabra Linn.. International Ayurvedic Medical Journal \{online\} 2020 \{cited November, 2020\} Available from:

http://www.iamj.in/posts/images/upload/4960_4968.pdf 